Editorial

\title{
Cermets and Hardmetals
}

\author{
Kevin Plucknett \\ Department of Mechanical Engineering, Dalhousie University, Halifax, NS B3H 4R2, Canada; \\ kevin.plucknett@dal.ca; Tel.: +1-902-494-3297 \\ Received: 14 November 2018; Accepted: 17 November 2018; Published: 19 November 2018
}

check for updates

\section{Introduction and Scope}

Cermets and hardmetals combine the most favorable characteristics of ceramics and metals, namely the high hardness and elastic moduli of the former, and the ductility and toughness of the latter. As a consequence, these materials have found widespread application in a broad range of demanding wear and/or corrosion applications, as both bulk materials and coatings. Common cermet and hardmetal uses include tooling for grinding, cutting, and machining; mechanical seals; friction surfaces; aerospace coatings; etc. The most ubiquitous examples of these ceramic-metal composites are 'hardmetals', which are based on WC-Co, and have been actively developed for nearly 100 years. Somewhat more recently, lighter weight cermet systems, based on alternate carbides, borides and/or nitrides, have grown in prominence.

The mechanical, tribological, and corrosion properties of these cermet and hardmetal systems are highly dependent upon both their composition and microstructure, and there is a continuing emphasis on the improvement of these characteristics for new generations of these materials. There is also an increasing drive towards the development of nanostructured cermets and hardmetals, particularly for improvements that can be achieved in terms of their wear response. In many usage scenarios, combined tribo-corrosion environments are also encountered; in such instances, the simultaneous physical and chemical demands on the materials can be extreme. Consequently, there is a growing demand for new cermet and hardmetal systems, and this is reflected in a continuing emphasis on research in these materials. The primary aim of this Special Issue on Cermets and Hardmetals is therefore to provide a platform for researchers to overview the current state-of-the-art in the development, characterization, and applications of high performance ceramic-metal composites.

\section{Contributions}

The current special issue, with a focus on cermets and hardmetals, brings together seven scientific research papers [1-7] that investigate various aspects of these materials. The papers are broadly divided between WC-based hardmetal systems [1-4], lower density carbides including TiC [5] and $\mathrm{NbC} \mathrm{[6],} \mathrm{and} \mathrm{mixed} \mathrm{oxide-carbide} \mathrm{systems} \mathrm{[7].} \mathrm{In} \mathrm{two} \mathrm{examples,} \mathrm{the} \mathrm{hardmetal} \mathrm{is} \mathrm{present} \mathrm{as} \mathrm{a} \mathrm{thin}$ coating on $\mathrm{Cr}-\mathrm{Ni}-\mathrm{Mo}$ based steel substrates [3,4]. There is a strong emphasis among these articles on the evaluation of the material's corrosion behavior [2-5], highlighting the importance of corrosion resistance in a great many applications, along with their tribological responses [3,7], mechanical behavior $[1,4,6,7]$, and the influence of grain size for near-nano variants [1,2].

In mixed carbide systems based on nano-WC, it has been shown that increasing the number of carbide types reduces the hardmetal corrosion resistance, while reducing the starting powder size, and hence the final carbide grain size also reduces the corrosion resistance [2]. Here, it may be assumed that the grain boundary area has a strong influence in a galvanic corrosion scenario. Similarly, reducing the amount of Co binder increases the corrosion resistance [2], with selective leaching of Co noted in this study. In a similar vein, it was also shown for TiC-stainless steel cermets (grades 304L, 316L, and 410L) that corrosion resistance decreased with increasing steel binder content, while 
the steel composition also had a significant effect [5]; at the lowest binder contents (i.e., 10 vol.\% steel), the corrosion resistance was comparable to the steel on its own, while the cermet had a roughly three-orders of magnitude lower wear rate. In comparing WC-WB-Co and WC-FeCrAl coatings, it was shown that the latter exhibited slightly improved corrosion resistance [3], although the two systems were broadly comparable.

In terms of wear resistance, it has been typically observed that the wear response is dependent upon both hardness and fracture resistance. The WC-WB-Co and WC-FeCrAl coatings were both shown to have reasonably good wear resistance [3], in conjunction with a low coefficient of friction. In developing an oxide-carbide cermet system, with $\mathrm{TiC}$ additions to a predominantly $\mathrm{Al}_{2} \mathrm{O}_{3}$ ceramic phase, it was apparent that even small metal additions (up to $3 \mathrm{wt}$ \% of either $\mathrm{Nb}$ or $\mathrm{Ni}$ ) could improve densification following spark plasma sintering [7]. Even though a lower elastic modulus phase was incorporated, the increased densification resulted in both improved hardness and wear resistance. In contrast, Mo additions to a carbon-rich $\mathrm{NbC}$ system actually increased hardness while reducing the fracture resistance, as the Mo was able to react with free- $\mathrm{C}$ to form alloyed $(\mathrm{Nb}, \mathrm{Mo}) \mathrm{C}[6]$, thereby removing the softer $C$ phase from the cermet.

The presented papers highlight the breadth of ongoing research in this area, with the work conducted on an international level. In each case, advanced characterization techniques have been employed, further emphasizing the continuing need for improved materials to aid sustainability.

\section{Conclusions and Outlook}

Industrial demands on advanced material properties are ever increasing. Consequently, there is a major international focus on materials research across an almost unlimited spectrum of applications. Cermets and hardmetals constitute just one class of advanced materials, with uses invariably related to tribological and/or corrosion environments. As such, they continue to be widely studied and further developed as both bulk materials and coatings. New advances such as laser-based cladding and related additive manufacturing technologies (for example, binder jetting) are opening up new avenues for processing these materials, allowing unique solutions to industrial problems. At the same time, iterative compositional modifications continue to improve their physical properties, while additions of secondary components such a graphene are beginning to reveal further property enhancements. It can be readily seen that it is currently a very stimulating and exciting time to be researching these ceramic-metal composite systems, and this is only likely to increase in the future as we strive for ever increased properties, lowered production costs, and unique manufacturing solutions.

Finally, as guest editor, I would very much like to express my sincere gratitude to all of the contributing authors for making this Special Issue a valuable reference source on the topic of cermets and hardmetals. I would also like to extend my special thanks to the editorial team at Metals, and especially to Will Li and Natalie Sun, for all of their assistance and support throughout the preparation and publication of this Special Issue.

Conflicts of Interest: The author declares no conflict of interest.

\section{References}

1. Aleksandrov Fabijanić, T.; Ćorić, D.; Šnajdar Musa, M.; Sakoman, M. Vickers Indentation Fracture Toughness of Near-Nano and Nanostructured WC-Co Cemented Carbides. Metals 2017, 7, 143. [CrossRef]

2. Alar, Ž.; Alar, V.; Fabijanić, T.A. Electrochemical Corrosion Behavior of Near-Nano and Nanostructured WC-Co Cemented Carbides. Metals 2017, 7, 69. [CrossRef]

3. Brezinová, J.; Landová, M.; Guzanová, A.; Dulebová, L.; Draganovská, D. Microstructure, Wear Behavior and Corrosion Resistance of WC-FeCrAl and WC-WB-Co Coatings. Metals 2018, 8, 399. [CrossRef]

4. Azhideh, M.; Aghajani, H.; Pourbagheri, H. Surface Characterization and Corrosion Resistance of 36Cr-Ni-Mo4 Steel Coated by WC-Co Cermet Electrode Using Micro-Electro Welding. Metals 2017, 7, 308. [CrossRef] 
5. $\quad$ Onuoha, C.; Russell, Z.; Kipouros, G.; Farhat, Z.; Plucknett, K. The Aqueous Electrochemical Response of TiC-Stainless Steel Cermets. Metals 2018, 8, 398. [CrossRef]

6. Huang, S.; Baets, P.D.; Sukumaran, J.; Mohrbacher, H.; Woydt, M.; Vleugels, J. Effect of Carbon Content on the Microstructure and Mechanical Properties of NbC-Ni Based Cermets. Metals 2018, 8, 178. [CrossRef]

7. Kumar, R.; Chaubey, A.K.; Maity, T.; Prashanth, K.G. Mechanical and Tribological Properties of $\mathrm{Al}_{2} \mathrm{O}_{3}-\mathrm{TiC}$ Composite Fabricated by Spark Plasma Sintering Process with Metallic (Ni, Nb) Binders. Metals 2018, 8, 50. [CrossRef]

(C) 2018 by the author. Licensee MDPI, Basel, Switzerland. This article is an open access article distributed under the terms and conditions of the Creative Commons Attribution (CC BY) license (http:// creativecommons.org/licenses/by/4.0/). 